\title{
Deploying governance networks for societal challenges
}

\author{
Adegboyega Ojo a, , Sehl Mellouli ${ }^{\text {b }}$ \\ a The Insight Centre for Data Analytics, National University of Ireland, Galway, Insight Centre Building, IDA Business Park, Lower Dangan, Co. Galway, Ireland \\ b Management Information Systems Department, Laval University, Quebec City, Canada
}

\section{A R T I C L E I N F O}

\section{Article history:}

Received 11 March 2014

Received in revised form 9 March 2016

Accepted 6 April 2016

Available online 23 April 2016

\section{Keywords:}

Governance networks

Networked governance

Public-private partnership

Collaborative-networks

Crowdsourcing

Citizensourcing

Social innovation

\begin{abstract}
A B S T R A C T
Governments are increasingly engaging private sector organizations, civil society and citizens to tackle complex policy challenges through some forms of networked governance arrangements. These governance networks which in general facilitate flexibility, speed and innovation in government, when compared with traditional governance forms, are necessary to meaningfully govern smart societies characterised by many programs spanning policy domains and levels of governments. This article presents a conceptual framework for governance networks and applies the framework to describe and analyse six case studies presented as part of the Track on "Governing through Networks" of the International Conference on the Theory and Practice of Electronic Governance (ICEGOV2013) Conference. Insights from the analysis of these cases somewhat suggest that: 1) governance networks are still largely steered by government; 2 ) efficacy of governance networks is contingent on citizen's inclusion in the governance networks; and 3) mobile social media platforms could constitute a key infrastructure for enabling citizen participation in these governance networks. Important policy and research challenges in this domain include how to effectively motivate citizen participation in these networks and align the divergent views of the different actors collaborating in the network.
\end{abstract}

(c) 2016 Elsevier Inc. All rights reserved.

\section{Introduction}

The shape of the public organization and how it governs societal problems has changed dramatically in the last two decades. More than ever before, governments are dealing with other autonomous actors in order to realize their policy objectives (E.-H. Klijn, 2002). Moving from the traditional vending machine operating model of governments in which citizens, businesses and other non-state actors play passive role in service delivery and policy formulation (Kamensky, 2009), governments are now engaging in sophisticated institutional arrangements and Governance Networks to tackle the complex and dynamic needs of smarter societies. Typical needs of smarter societies include the governance of water and natural resources (Stein, Ernstson, \& Barron, 2011; Bodin \& Crona, 2009) in addition to integrated governance of education, health, economic, security and other sectors within the framework of inclusive and sustainable development programs like the Millennium Development Goals (MDG) and the Post 2015 Development Agenda (Swyngedouw, 2005; Huppé, Creech, \& Knoblauch, 2012). These networks in general may be targeted at solving problems, generating ideas, building relations and building trust (Janowski, Pardo, \& Davies, 2012).

\footnotetext{
* Corresponding author at: Insight Centre for Data Analytics, National University of Ireland Galway (NUIG), IDA Business Park, Lower Dangan, Galway, Republic of Ireland. E-mail addresses: adegboyega.ojo@insight-centre.org (A. Ojo), sehl.mellouli@fsa.ulaval.ca (S. Mellouli).
}

Governance Networks are composed of social networks of actors in addition to formal government systems of actors (Stein et al., 2011). Studies are showing that these non-formal social networks of nonstate actors are at least as important as formal institutions comprising state actors in terms of their contributions to the overall governance outcomes (Bodin \& Crona, 2009).

In general, three megatrends have accelerated a transition towards networked governance: 1 ) growth of outsourcing, 2) movement towards joined-up government service delivery, and 3) Digital Revolution, enabling communicating and collaboration with partners across organizational boundaries (Eggers \& Goldsmith, 2004).

However, networked governance as governance innovation poses a number of challenges commonly associated with the notion of the Hollow State (E.-H. Klijn, 2002). The Hollow State problematique is characterised by complex decision-making processes, and services delivery and policy implementation distributed among autonomous non-state actors (E.-H. Klijn, 2002). The complexity associated with Governance Networks is related to the difficulties in obtaining a shared understanding of the problem and reaching a certain level of agreement among network actors (Huppé et al., 2012).

This article provides a review of six studies on Networked Governance presented as part of the Track "Governing through Networks" of the ICEGOV2013 Conference (Beyond 2015 - Smart Governance for Smart Development), and follow-up discussions on these contributions held as part of the conference. The first study presents the case of public-private partnership in Ethiopia for implementing a unified utility billing system. The second study discusses how citizen involvement in 
the 2015 Development Agenda could be enabled by mobile devices. The third study examines the case of Korea's Government 3.0 program. The fourth study addresses how citizen participation could be enhanced through better accessibility features on government websites. Social media based communication strategies for governing MDGs in Nigeria is presented in the fifth study. The last study examines motivating factors for citizen participation in selective citizen-sourcing.

The paper is organized as follows. Section 2 provides the basic concepts on Governance Networks. Section 3 introduces the analytical framework used to analyse the case studies that are described and analysed in Section 4. Section 4.3 provides a synthesis from the analysis of the cases while discussion and concluding remarks are presented in Section 5 .

\section{Concepts}

The term governance has been used in a variety of ways, but is most often presented as an attempt to improve coordination between relatively dependent actors for the purpose of solving societal problems (E. Klijn, 2008). There are at least four dominant perspectives or conceptions of governance (E.-H. Klijn, 2008): as good governance or corporate governance; as New Public Management or Market Governance; as multi-level governance or intergovernmental relations and as network governance. The good governance perspective focuses on the principles of a properly governed state and how government operates. The second school of governance as new public management focuses on how to improve the performance and accountability of government by shifting the role of government to goal setting and implementation to non-state actors. The third perspective of governance as inter-governmental relations or multi-level governance stresses the use of networks crossing agency boundaries and levels of government for addressing problems. The fourth notion of governance as Network Governance (our main focus in this article) is concerned with governance which takes place within networks of public and non-public actors, characterised by complex processes. All four types share an emphasis on the process of governing rather than the structure of government and the limits to government capacity.

Governance Networks could be described as self-organizing interorganizational networks characterised by: independencies between organizations; continuing interactions among members caused by the need to exchange resources and negotiate shared objectives; gamelike interactions rooted in trust and regulated by rules negotiated and agreed by network participants; and a significant degree of autonomy from the state (Dawkin \& Colebatch, 2006). Governance Networks (networks) are composed of diverse participants from all levels (e.g., local, national, global) and sectors (e.g., business, government, civil society) of society, and do not merely aggregate resources, but are structured to take advantage of the fact that each participating sector brings different resources to the fore (Huppé et al., 2012). These networks may selforganize within bounds towards certain policy-making functions, where stakeholders are brought into the decision-making processes, ranging from consultations to full-fledged peer-decision-making roles. In the latter, the government is a co-participant, often a convener and co-decision-maker (Huppé et al., 2012). Social networks of non-state actors are an important subset of actors in a Governance Network (Stein et al., 2011). However, the efficacy of Governance Networks is contingent on the integration of activities of social networks of actors and formal governance structures (Bodin \& Crona, 2009).

In terms of network organization, there are at least two models of Governance Networks (Huppé et al., 2012). The first involves active steering by governments or other centralised governance authorities. The second model focuses on Governance Networks as self-organizing systems. Concrete Governance Networks are situated along the steering versus self-regulating spectrum.

From the research perspective, three Governance Networks types are dominant - Policy Networks, Service Delivery and Policy
Implementation Networks, and Governing Networks (E.-H. Klijn, 2008). Policy Networks focus on decision making and effects as well as power relations on issues and agenda setting. With roots in Political Sciences the line of enquiry for this network type is centred around identifying the main actors involved in decision making, the nature of power relations and the effect of these two issues on decision making. Service Delivery and Policy Implementation Networks and Governance Networks are focused on inter-organizational coordination, effective policy and service delivery and integrated policies (or policy coherence). Grounded in Organizational Sciences and Inter-organization Theory, research on Governance Networks investigates how to effectively and efficiently coordinate complex integrated services and what kind of mechanisms can be adopted to achieve this. The third type is focused on solving societal problems, managing horizontal governance relations, and connecting Governance Networks with traditional institutions and deliberation processes. With roots in Public Administration, research interest here is how to manage Governance Networks and integrate them with tradition institutions.

Operationally, as a typical collaborative network, a Governance Networks must be able to effectively organize its workings and information exchange (Ojo, Janowski, \& Estevez, 2010). The development of the network typically proceeds in four major stages - creation, in which the collaboration among network actors is initiated; operation - in which actions and information exchange commences; evolution - in which changes are made to the structure and workings of the network to better meet the shared goal, and dissolution - where the network is transformed for some other purposes or dissolved.

Finally, the design of Governance Networks includes the following core aspects: 1) shared goal - the objective of the network, 2) governance - how the governance network itself will be governed, 3) administration - specification of the different actors in addition to how the network will be coordinated, 4) delivery - processes to achieve the desired goals of the Governance Network. The design of these parts could be guided by a set of collaboration principles elaborated, e.g. in Ojo et al. (2010). The core concepts related to Governance Networks are highlighted in Fig. 1.

\section{Analytical framework}

We describe here a framework for analysing Governance Networks based on the elaboration of the concepts described in Section 2. The goal of the framework is to enable characterisation, analysis and consolidation of patterns in structures and strategies employed in the cases of Governance Networks. The concepts presented above could be related based on the elaboration of Governance Networks presented in Eggers \& Goldsmith (2004). In their model, the building blocks of a Governance Networks were identified to include a central strategy element, and four structural or supporting elements: network design and activation, Information Technology enabler, Human Capital, and Performance and integration.

The strategy element addresses the shared and individual objectives of actors in the network. Network design addresses how information and resources (including human) flow within the network, how the network is governed and ultimately how the network will achieve its goals. The Connecting element is related to the enabling technology for partners to share knowledge, business processes, decision-making, client information and workflows. The accountability element involves how the network will ensure that success, failure and issues that may arise can be appropriated to actors in the network. The fifth element Human Capital or resources addresses how the new set of competencies and capabilities that are required within the network, particularly on the part of government actors, will be developed. These elements may be grouped into two major elements - "Strategy" for the Governance Network and "Structures" required for implementing the strategy to achieve the desired network goals. Based on the established relationship between Organizational Strategy and Organizational Structure (Cowherd \& Luchs, 1988; Zheng, Yang, \& McLean, 2010), we conjecture 


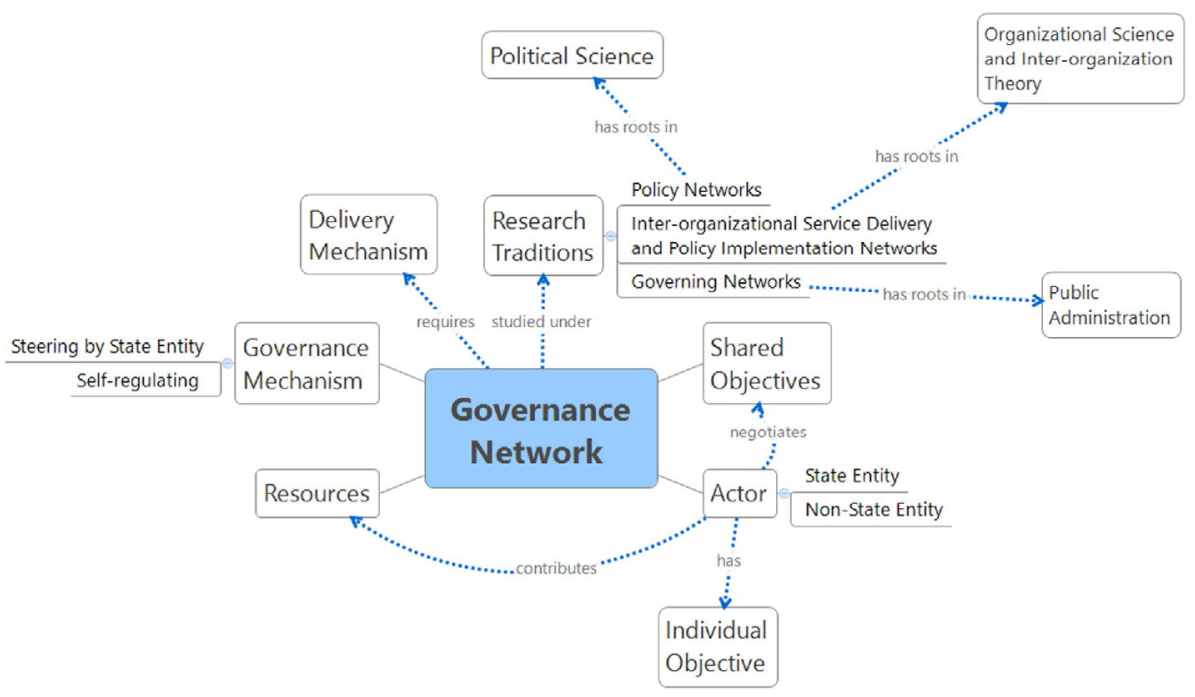

Fig. 1. Governance network concepts.

that Network Strategy determines and shapes Network Structure. In addition, Network Structure and Network Strategy both contribute to achieving Network Goals. These relationships are depicted in Fig. 2.

\section{Cases}

We employ the analytical model described in Section 3 to explore the six cases of Governance Networks described below. The cases are described in Section 4.1, and analysed in Section 4.2 with some synthesis in Section 4.3.

\subsection{Description}

An overview of each case is presented first, followed by a characterization of the associated Governance Networks in terms of their desired outcomes, strategies and enabling structures employed.

\subsubsection{Governance of a public-private partnership initiative in Ethiopia}

The case presented in Belachew (2013) is an ongoing public-private arrangement for delivering a Universal Billing System (UBS) in Ethiopia. The initiative is aimed at unifying the bill payment systems of various utilities for citizen convenience. It will enable citizens to pay their utility bills to Addis Ababa Water \& Sewage Authority (AAWSA), Ethiopian Electric Power Company (EEPCO) and Ethio-Telecom (ET). The initiative is being implemented as a PPP model, where the Ministry of Communication and Information Technology (MCIT) represents the public sector part of the partnership and the principal owner of the project. The utility

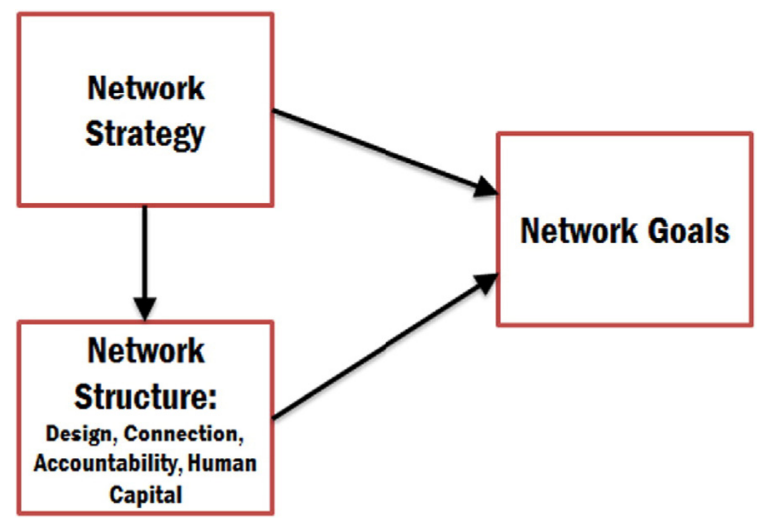

Fig. 2. Analytical model relating network strategy, structure and goals. companies (ET, EEPCO and AAWSA) are the principal beneficiaries from the private sector actors.

The goal of the governance network is towards better delivery or implementation of public services (or utilities) through a unified billing system. The network is a typical Service Delivery and Policy Implementation Network. Hence, the core concern here is how to effectively coordinate the implementation of the UBS initiative between the public organization and the three utility authorities. In the Public-Private partnership arrangement (the strategy), the government party (MICT) plays the steering role and coordinates the interactions among the utility authorities. A federated governance model composed of three management layers - executive, steering and project/operational committees is being adopted for managing the network (the structure).

We make three observations with respect to the operation of this network (Belachew, 2013). First is the low participation of end users in the management and governance of the network. The second is that the power in the Governance Network resides with the government party. The third observation and somewhat a consequence of the second recommendation is that funding and end-user ownership constitute two challenges that may face this type of Governance Networks.

\subsubsection{Enabling citizen participation in governing the post 2015 develop-} ment agenda

The second case described in Halder (2013) presents a governance network proposed for the management of the Post 2015 Development Agenda. This case illustrates the role of citizens in gathering accurate information about development initiatives through mobile devices. It proposes a partnership between citizens and governments to deal with different governance issues related to development programs. The proposed framework specifies different communication levels between government and citizens, from receiving primary information about initiatives to providing feedback on outcomes of policies or development initiative by responsible government authorities or development agencies. Four main actors are involved in the proposed Governance Network: 1) Central Government Authority responsible for implementing the Post 2015 Development Agenda, 2) Local Authorities involved in implementing the initiative, 3 ) citizens and 4) private organization responsible for providing the enabling mobile technology infrastructure.

The governance network described in this case is a typical example of Governance Network concerned with how citizen participation in program governance can lead to better program outcomes (goal). In this case, crowdsourcing is proposed as network governance strategy to deliver citizen-centric governance of the Post-2015 Development Agenda. Challenges associated with this case include how to integrate 
the less formal Governance networks with traditional development management institutions. Another challenge involves how to effectively provide citizens with the contents required to make informed arguments, as well as how to negotiate various value judgements of the participants or crowd. A requisite technological infrastructure to support this form of Governance Networks is a mobile "crowdsourcing" or open participation platform. The management of the proposed governance network still requires steering by the central government authority.

The authors of this case further identified some issues that may affect the successful implementation of the proposed governance network. The first issue is related to the need for ethical management of personal information and contributions of the participating users. The second is the need to promote the use of the mobile governance and participatory platforms for citizen adoption and use. The possibility of engaging international development organizations and NGOs in the Governance Networks was also raised.

\subsubsection{Korea's GOVERNMENT 3.0 networked governance paradigm}

The third case described in Nam (2013) is centred on the Korean Government's "Government 3.0" Initiative. At the core of this paradigm is a collaborative, cross-boundary Governance Network for delivering personalized services to citizens and enabling better citizen engagement through open information and data initiatives. Government 3.0 is a strategy for service-oriented government to provide low-cost but high-quality services for citizens. These services are highly personalized for citizens and businesses and targeted at their needs. In addition, Government 3.0 as conceived by the Korean Government directly pursues transparency and openness of government. Three factors are contingent to achieving the Government 3.0 goals (Nam, 2013): 1) integrated, i.e. cross-boundary, cross-organizational, cross-agency, and cross-departmental administration, 2) cross-boundary information sharing and collaboration driven by digitization and informatization, and 3) scientific data-driven administration. Governing the Government 3.0 initiatives involves three categories of actors - government authorities, citizens and businesses.

The Korean Government 3.0 is both a Service Delivery and Policy Implementation Network, and Governance Network aiming to deliver highly personalised services to citizens and businesses and engage both citizens and businesses in its policy making. The strategy in this case includes the adoption of the "Integrated Administration" (or whole-of-government) approach for service delivery and open data in agency services and operations. The core concerns in governing the Government 3.0 network includes how to effectively coordinate the delivery of personalised services across agencies and how to effectively mobilize and engage citizen in the so-called "citizen-government governance" arrangements (Nam, 2013). A number of key structures are required to implement the network strategy: cross-agency interoperability framework, mobile service infrastructure, open data platforms and marketplaces, and cloud computing infrastructure. The government maintains the steering role in this governance network.

The authors identified at number of concerns about the Korean Government 3.0 initiative, including: how to effectively implement the inherent service delivery network and governing network within a single framework; the lack of detailed elaboration on the mechanisms for realizing these two inherent networks; the inherent difficulties in opening up government agencies due to the traditional bureaucratic and closed organizational culture; and lastly the threat to continuity or sustainability of the initiative after the current political dispensation.

\subsubsection{Accessibility for citizen participation in governance networks in Saudi Arabia}

The case described in Al-faries, Al-khalifa, Al-razgan, \& Al-duwais (2013) focused on the importance of accessibility in citizen engagement and service delivery, guided by the study of the websites of five ministries in Saudi Arabia including Foreign Affairs, Civil Services, Real Estate development, Interior and Public Pension. The goal of the study was to identify whether the online services met the Web Content Accessibility Guidelines (WCAG) principles, and the conformance levels for the selected ministries.

Albeit this case does not explicitly describe a specific Governance Network, accessibility is an important issue in Service Delivery and Policy Implementation Networks. Structures required to support the implementation of the accessibility strategy include processes to ensure conformance to the Web Content Accessibility Guidelines (WCAG) 2.0 Guidelines.

The study noted that none of the reviewed websites fully met the WCAG guidelines. The poor accessibility of these websites creates a barrier to engaging citizens and external stakeholders in government related activities. The need to promote better accessibility in general within government was recommended.

\subsubsection{Communication strategy for MDG governance in Nigeria}

The case described in Akpa \& Olaniyan (2013) presents the strategy for better communication among stakeholders in the governance of the Millennium Development Program (MDGs). The communication strategy complements existing structures in the current MDG Governance Network in Nigeria and bridges the communication gap between government and citizens in particular. There are several actors typically involved in MDG governance. A major actor is the Office of the Senior Special Adviser to the President on MDG (OSSAP MDGs) responsible for overseeing the implementation of the MDGs across levels of government. The network also includes civil societies and international organizations. The authors argue for the centrality of citizens as an important class of actor that should be engaged in the implementation of MDGs.

This case presents another instance of a typical "Governing Network" for coordinating the implementation of the MDGs. The main concern here is how to improve the communication among current network members and include disengaged parties such as citizens. Towards this, a communication strategy involving the use of different technology infrastructures and services is proposed. In addition to the existing Oversight and Advisory office at the Presidency and desk offices at various ministries, three related technology structures were recommended - government to government communication infrastructure across ministries, department and agencies (MDAs) and levels of government; the use of social media as a communication platform; and the use of mobile technology to engage citizens.

However, a few obstacles to the implementation of the communication strategy were highlighted in the study. The first is that most citizens are yet to have access to computer and the internet. The second challenge is that while there is good penetration of mobile phones, the cost of mobile services is still prohibitive for a large segment of the populace. Another issue is the unreliability of the power supply needed to operate the proposed initiatives.

\subsubsection{Selective crowdsourcing for open process innovation in government}

The case (Seidel, Thapa, Plattfaut, \& Niehaves, 2013) presents findings from a study on willingness of citizens to participate in Open Government innovation initiatives to inform strategies for engaging citizens. It involves public sector process innovation through citizensourcing. It also examines the factors that may affect the willingness of expert citizens to participate. While the strategies informed by the findings could underpin selective citizensourcing for any Governance Networks, the case presented in the paper (Seidel et al., 2013) is associated with the Service Delivery and Policy Implementation Network.

The main concern in this governance network is how to selectively engage citizens in open process innovation activities. Possible strategies for selective crowdsourcing include: targeting expert citizens rather than non-experts for both simple and complex tasks, since experts appear more willing to participate in selective crowdsourcing; possibly providing financial incentives to non-experts citizens in selective crowdsourcing; and targeting younger people possibly with some financial incentives when appropriate. Regarding enabling structures, 
Table 1

Features of governance networks from six cases.

\begin{tabular}{|c|c|c|c|c|c|}
\hline Case & Type & Goal & Strategy & Structure & Issues \\
\hline Case 1: PPP in Ethiopia & $\begin{array}{l}\text { Service delivery and policy } \\
\text { implementation network }\end{array}$ & $\begin{array}{l}\text { o How to effectively coordinate the } \\
\text { implementation of the Unified Billing } \\
\text { System initiative among the private } \\
\text { organization and the three utility } \\
\text { authorities }\end{array}$ & $\begin{array}{l}\text { o Public-private partnership, with } \\
\text { private party building the Unified } \\
\text { Billing System }\end{array}$ & & $\begin{array}{l}\text { o Low participation of end-user } \\
\text { o Imbalance in power distribution } \\
\text { o Resourcing initiatives }\end{array}$ \\
\hline Case 2: governing post 2015 & Governing network & $\begin{array}{l}\text { o How to integrate crowdsourcing with } \\
\text { the traditional governance institutions } \\
\text { o How to provide citizen with } \\
\text { appropriate contents } \\
\text { o How to negotiate different values } \\
\text { judgements of the crowd }\end{array}$ & o Engagement and crowdsourcing & $\begin{array}{l}\text { o Mobile participation platform and } \\
\text { mobile governance app }\end{array}$ & $\begin{array}{l}\text { o Legal issues relating to identity and } \\
\text { use of citizen-generated contents } \\
\text { o Promotion of mobile governance } \\
\text { platform } \\
\text { o Engagement of international NGOs }\end{array}$ \\
\hline Case 3: Korean Gov 3.0 & $\begin{array}{l}\text { Service Delivery and Policy } \\
\text { Implementation and } \\
\text { Governing Network }\end{array}$ & $\begin{array}{l}\text { o How to effectively coordinate } \\
\text { cross-agency } \\
\text { collaboration in delivering } \\
\text { personalised services } \\
\text { o How to sustain citizen engagement and } \\
\text { participation in Governance Networks }\end{array}$ & $\begin{array}{l}\text { o So-called integrated-administration } \\
\text { (or whole of government) and open } \\
\text { government }\end{array}$ & $\begin{array}{l}\text { o Cross-agency interoperability } \\
\text { framework, mobile service } \\
\text { infrastructure, open data platform } \\
\text { and marketplace, cloud computing } \\
\text { infrastructure }\end{array}$ & $\begin{array}{l}\text { o Joint implementation of two } \\
\text { constituent networks - the service } \\
\text { delivery and governing network } \\
\text { o Lack of details on mechanisms for } \\
\text { implementing the network } \\
\text { o Resistance in opening up due to } \\
\text { current closed bureaucratic culture } \\
\text { o Threat to sustainability of network } \\
\text { due to political environment }\end{array}$ \\
\hline $\begin{array}{l}\text { Case 4: service network in } \\
\text { Saudi Arabia }\end{array}$ & $\begin{array}{l}\text { Service delivery and policy } \\
\text { implementation }\end{array}$ & $\begin{array}{l}\text { o How to ensure greater accessibility of } \\
\text { contents and services to citizens }\end{array}$ & $\begin{array}{l}\text { o Implementation of the Web Contents } \\
\text { Accessibility } 2.0 \text { guides on major } \\
\text { websites }\end{array}$ & $\begin{array}{l}\text { o Processes for implementing WCAG } \\
2.0 \text { in agencies }\end{array}$ & $\begin{array}{l}\text { Disregard for WCAG guidelines } \\
\text { among contracted developers } \\
\text { o Promotion and awareness of WCAG } \\
\text { guidelines in agencies }\end{array}$ \\
\hline $\begin{array}{l}\text { Case 5: MDG governance in } \\
\text { Nigeria }\end{array}$ & Governing network & $\begin{array}{l}\text { o How to improve communication } \\
\text { among network members and include } \\
\text { disengaged citizens }\end{array}$ & $\begin{array}{l}\text { o Leverage technologies that enable } \\
\text { better communication within } \\
\text { government and with citizens }\end{array}$ & $\begin{array}{l}\text { o Government-to-government } \\
\text { infrastructure, processes and tools to } \\
\text { engage with citizens on social media } \\
\text { o Mobile engagement platform }\end{array}$ & $\begin{array}{l}\text { o Poor quality of internet access } \\
\text { among citizens } \\
\text { Cost of mobile services for some segment } \\
\text { of the society, unreliable power supply }\end{array}$ \\
\hline $\begin{array}{l}\text { Case } 6 \text { : selective } \\
\text { crowdsourcing for open } \\
\text { innovation }\end{array}$ & $\begin{array}{l}\text { Service delivery and policy } \\
\text { implementation network }\end{array}$ & $\begin{array}{l}\text { o What strategy can be employed to en- } \\
\text { gage expert citizens? }\end{array}$ & $\begin{array}{l}\text { o Target citizen experts rather than } \\
\text { non-experts for both simple and } \\
\text { complex tasks } \\
\text { o Financial incentives may be more } \\
\text { important for non-experts than } \\
\text { expert citizens in selective } \\
\text { crowdsourcing } \\
\text { o Targeting younger people as they } \\
\text { better respond to financial incentives }\end{array}$ & $\begin{array}{l}\text { o Financial resources in addition to } \\
\text { traditional crowdsourcing } \\
\text { infrastructure. }\end{array}$ & \\
\hline
\end{tabular}


processes to target expert citizen and financial resources to incentivize participants were considered important.

\subsection{Analysis}

The six cases considered in Section 4.1, focused on two types of core Governance Networks - Service Delivery and Policy Implementation Networks and Governance Networks. On the one hand, Service Delivery and Policy Implementation Networks aimed at improving coordination among network members and improving engagement of citizens, for instance through better accessibility. Governance Networks reviewed, on the other hand, address how to include citizens in the network and integrate the citizen participation environment with traditional decision-making environment within government. Public-Private Partnerships, Crowdsourcing and Selective Crowdsourcing are major strategic approaches adopted in considered Governance Networks. In implementing these strategies, core infrastructures and processes identified include mobile participation platforms; cross-agency interoperability frameworks; open data platforms; cloud infrastructure; social media based communication processes, and financial resources for incentivising. See Table 1 for details. Power balance, legal issues on the use of citizen-generated contents and citizen identities, poor awareness of accessibility standards in delivering contents to citizens, and resistance to opening up agency information systems to make available open government data, are some of the issues highlighted in the various Governance Networks.

\subsection{Synthesis}

This section consolidates the findings from the analysis of the six case studies in Section 4.2 and the discussions held among case authors and other participants of the ICEGOV 2013 workshop on Governing through Networks. The findings include:

o Governance Networks are still largely steered by government, with distribution of power in favour of the owning government entity.

o While there is an agreement that government entities should distribute decision-making powers and operate more like peers in Governance Networks arrangements, it is necessary that government entities initiate and clearly demonstrate deep commitments in such partnerships or collaboration for the arrangement to be effective. In fact, participants stressed from experience that, third-party initiated Governance Networks arrangements are very risky.

o In arrangements involving citizens, clear and targeted communication strategy by governments through social media and traditional mass communication channels in local languages, and identification of champions are critical for government-citizen partnerships.

o Government is ultimately responsible for building trust with partners and remains accountable for the overall outcome of the networked governance arrangement.

o Engaging citizen experts may be more feasible in selective crowdsourcing or citizensourcing and the use of financial incentives is still relevant in crowdsourcing.

o The use of mobile social media platforms is central to citizen inclusion in the Governance Networks.

\section{Conclusions}

The set of cases reviewed in this article agree on a common thread to engage external actors and citizens in Governance Network. The cases also unanimously show the dominance of government entities in Governance Networks at least for Service Delivery Networks and Governing Networks. Unfortunately, since no Policy Network instances was included as part of the cases, structural analysis of the Governance Networks in terms of inclusion of other actors such as businesses, civil society and international organizations and the roles they play in these networks could not be explored in our analysis. Nevertheless, the syntheses from the cases covered in this article reinforce the known facts on the centrality of the government parties in any Governance Network. The synthesis also suggests that in the wider Smart Society context where social actions are initiated by non-state actors, there may be significant challenges in getting government parties to support such initiatives. Another important aspect of Governance Networks not well highlighted in the cases but discussed extensively in the literature is the role of trust building in the overall success of governance network. Given the importance of social capital in the efficacy of Governance Networks (Huppé et al., 2012), providing strategies for building trusts across the network is very important. A general shortcoming of the reviewed cases is that they do not offer additional insights on the side effects or consequences of the Governance Networks, such as the hollow state effect (E.-H. Klijn, 2002). Finally, we believe that some of these findings will provoke future focused studies on Governance Networks in general and in the context of Smart Societies in particular.

\section{References}

Akpa, E. R., \& Olaniyan, K. (2013). Learning from Experience : Developing an ICT Based Communication Strategy for sustaining the MDGs in. 7th International Conference on the Theory and Practice of Electronic Governance, ICEGOV 2013, Seoul Korea. ACM International Conference Proceedings Series. ACM Press.

Al-faries, A., Al-khalifa, H. S., Al-razgan, M. S., \& Al-duwais, M. (2013). Evaluating the Accessibility and Usability of Top Saudi E-Government Services. 7th International Conference on the Theory and Practice of Electronic Governance, ICEGOV 2013, Seoul Korea. ACM International Conference Proceedings Series. ACM Press.

Belachew, M. (2013). Public Private Partnerships ( PPP ) in the E-Government Initiatives for Developing Nations : the case of Ethiopia. 7th International Conference on the Theory and Practice of Electronic Governance, ICEGOV 2013, Seoul Korea. ACM International Conference Proceedings Series. ACM Press.

Bodin, Ö., \& Crona, B. I. (2009). The role of social networks in natural resource governance: What relational patterns make a difference? Global Environmental Change, 19(3), 366-374. http://dx.doi.org/10.1016/j.gloenvcha.2009.05.002.

Cowherd, D. M., \& Luchs, R. H. (1988). Linking organization structures and processes to business strategy. Long Range Planning, 21(5), 47-53. http://dx.doi.org/10.1016/ 0024-6301(88)90104-5.

Dawkin, J., \& Colebatch, H. K. (2006). Governing through institutionalised networks : The governance of Sydney Harbour. Land Use Policy, 23, 333-343. http://dx.doi.org/10. 1016/j.landusepol.2004.09.006.

Eggers, W. D., \& Goldsmith, S. (2004). Government by Network - The New Public Management Imperative, 1-32.

Halder, B. (2013). Mobile-based Crowdsourcing Platform for Post-2015 Governance : Possibilities for Developing Countries. 7th International Conference on the Theory and Practice of Electronic Governance, ICEGOV 2013, Seoul Korea. International Conference Proceedings Series. ACM Press.

Huppé, G. A., Creech, H., \& Knoblauch, D. (2012). The frontiers of networked governance. Sustainable Development, 1-40.

Janowski, T., Pardo, T. a., \& Davies, J. (2012). Government information networks - mapping electronic governance cases through public administration concepts. Government Information Quarterly, 29, S1-S10. http://dx.doi.org/10.1016/j.giq.2011.11.003.

Kamensky, J. (2009). Governing through networks. The Public Manager, 10-12.

Klijn, E. (2008). Governance and governance networks in Europe : An assessment of 10 years of research on the theme, Public Management Review, vol . 10 , issue 4 : 505-525. (Public Management Review, 10, 505-525).

Klijn, E. -H. (2002). Governing networks in the hollow state: Contracting out, process management or a combination of the two? Public Management Review, 4(2), 149-165. http://dx.doi.org/10.1080/14616670210130516.

Klijn, E. -H. (2008b). Governance and governance networks in Europe. Public Management Review, 10(4), 505-525. http://dx.doi.org/10.1080/14719030802263954.

Nam, T. (2013). Government 3.0 in Korea : Fad or Fashion ? 7th International Conference on the Theory and Practice of Electronic Governance, ICEGOV 2013, Seoul Korea. ACM International Conference Proceedings Series. ACM Press.

Ojo, A., Janowski, T., \& Estevez, E. (2010). Whole-of-government approach to technology strategy management: Building a sustainable collaborative technology environment in government. Information Polity, 16(3), 243-260.

Seidel, C. E., Thapa, B. E. P., Plattfaut, R., \& Niehaves, B. (2013). Selective Crowdsourcing for Open Process Innovation in the Public Sector - Are Expert Citizens Really Willing to Participate? 7th International Conference on the Theory and Practice of Electronic Governance, ICEGOV 2013, Seoul Korea. ACM International Conference Proceedings Series. ACM Press.

Stein, C., Ernstson, H., \& Barron, J. (2011). A social network approach to analyzing water governance: The case of the Mkindo catchment, Tanzania. Physics and Chemistry of the Earth, Parts A/B/C, 36(14-15), 1085-1092. http://dx.doi.org/10.1016/j.pce.2011.07.083.

Swyngedouw, E. (2005). Governance innovation and the citizen: The Janus face of governance-beyond-the-state. Urban Studies, 42(11), 1991-2006. http://dx.doi.org/ $10.1080 / 00420980500279869$. 
Zheng, W., Yang, B., \& McLean, G. N. (2010). Linking organizational culture, structure, strategy, and organizational effectiveness: Mediating role of knowledge management. Journal of Business Research, 63(7), 763-771. http://dx.doi.org/10.1016/j. jbusres.2009.06.005.

Adegboyega Ojo is a Research Fellow and leads the E-Government Group at The INSIGHT Center for Data Analytics, National University of Ireland, Galway; Republic of Ireland. His research focuses on how to drive innovations in government organizations through the applications of Semantic Web, Linked Open Data and Collaboration technologies. His current portfolio of research and development projects is funded under the Seventh Framework Programme of the European Commission. Before his current role, he worked as Academic Program Officer, Research Fellow and Post-doctoral Fellow at the Center for Electronic Governance, United Nations University - International Institute for Software Technology (UNU). At UNU, his work benefitted several governments including Macao, Korea, Mongolia, Colombia, Cameroon and Nigeria. He has published widely in the areas of Strategies, Architecture and Standards, e-Participation, Open Governance and Open Data. He obtained his PhD at the University of Lagos, Nigeria (1998), where he was appointed Senior Lecturer and Associate Professor in Computer Science in 2003 and 2012 respectively. He is also Adjunct Lecturer at the National University of Ireland, Galway.
Sehl Mellouli is an associate professor at the Management Information Systems Department, Faculty of Business Administration, Laval University, Quebec, Canada. He received his Ph.D in Computer Science from Laval University. His main research interests are related to e-government, smart cities, intelligent systems, and knowledge management. Professor Mellouli has several publications in well-known journals and conferences. He acts as a reviewer for different journals. He also acted for program committees and organization committees of different conferences. Professor Mellouli is a member of the board of the digital government society. He is a former member of the North American Digital Government Group. He is currently a member of the eGovPolinet research consortium funded by the European Union. 